\title{
Diversity and distribution of true mangroves in Myeik coastal areas, Myanmar
}

\begin{abstract}
A total of 21 species of true mangroves, namely Rhizophora apiculata, R. mucronata, Bruguiera gymnorhiza, B. sexangula, B. cylindrica, B. parviflora, Ceriops tagal, C. decandra, Avicennia alba, A. officinalis, A. marina, Xylocarpus granatum Heritiera fomes, X. moluccensis, Sonneratia alba, S. graffithii, Heritiera forms, H. littoralis, Aegialitis rotundifolia, Aegiceras corniculatum, Excoecaria agallocha and Nypa fruticans were recorded from five study sites; Kapa, Masanpa, Panadoung, Kywekayan and Kyaukphyar in Myeik area from December 2017 to July 2018. Among these, 2 species were Near Threatened (NT), 1 species was Critically Endangered (CR) and 1 species was Endangered (EN) under the IUCN Red List. Rhizophora apiculata R. mucronata,Avicennia officinalis, Sonneratia alba, Aegiceras corniculatum, and Nypa fruticans were distributed in all 5 study sites whereas Bruguiera gymnorrhiza and Heritiera littoralis are rarely found only in one study site. Kapa was designated as an area of the most abundant species composition representing 17 species, whereas Kyaukphyar representing 12 species as the least composition. The mangrove area in Kyaukphyar is the most degraded area among the study sites, due to urban development and industrialization. The environmental parameters such as salinity and temperature of seawater, and temperature and $\mathrm{pH}$ of soils of each study site were presented.
\end{abstract}

Keywords: diversity and distribution, Myanmar, Myeik coastal areas, species composition, taxonomy, true mangroves
Volume 8 Issue 5 - 2019

\author{
Tin-Zar-Ni-Win, ${ }^{\prime}$ Tin-Tin-Kyu, ${ }^{2} \cup$ Soe-Win ${ }^{3}$ \\ 'Marine Biologist, Fauna and Flora International (FFI), Myanmar \\ ${ }^{2}$ Department of Marine Science, Myeik University, Myanmar \\ ${ }^{3}$ Department of Marine Science, Mawlamyine University, \\ Myanmar
}

Correspondence: Tin-Zar-Ni-Win, Marine Biologist, Fauna and Flora International (FFI), Myanmar, Email tinzar2019@outlook.com

Received: August 25, 2019 | Published: September 17,2019

\section{Introduction}

Myanmar possesses a long coastline which can be divided into three Coastal Regions, namely the Rakhine Coastal Region (from the mouth of Naaf River to Maw Tin Point), the Ayeyarwady Delta and the Gulf of Mottama Coastal Region (Maw Tin Point to the Gulf of Mottama) and Taninthayi Coastal Region (from the Gulf of Mottama to the Mouth of Pakchan River), extending along the Bay of Bengal and Andaman Sea. ${ }^{1}$ Among these, Tanintharyi Coastal Region, with over 800 islands, possesses the longest coastline about $1200 \mathrm{~km}$ in length and shows the richest diversity of coastal habitats including mangroves dominant exclusively in Myeik coastal zone.

There are estuaries with deltaic systems, and numerous offshore islands along with a considerable diversity of coastal habitats, including mangroves, seagrass meadows, coral reefs, sandy beaches and mudflats along the three Coastal Regions of Myanmar. ${ }^{2}$ Myanmar coastal habitats held an estimated 437,000 ha of extant mangrove ecosystems, showing the 8 th largest mangrove forest in the world (4\% of the world mangroves) and the 3rd largest in South East Asia (8.8\% of South East Asia mangroves. ${ }^{3}$ As the present studies, mangroves of Myanmar comprise over eighty species of mangroves and its associate species. ${ }^{4}$ The Tanintharyi Region still holds large areas of mature mangroves, including the largest remaining mangrove area in Myanmar with $>150,000$ ha. $^{5}$

Mangroves of Myeik coastal zone dominate along the deltaic areas of the Tanintharyi River. Recently, mangrove forests in Myeik coastal zone are being degraded and destroyed on a large scale through natural disturbances and anthropogenic activities such as transforming to agriculture land, aquaculture ponds, salt ponds/land etc., which are major causes of the degradation and loss of mangrove ecosystems. ${ }^{6}$ The objective of this study is to know the diversity and distribution of mangrove plants in Myeik coastal areas.

\section{Materials and methods}

The present study was conducted in 5 study sites of mangrove

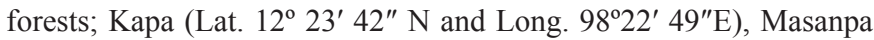

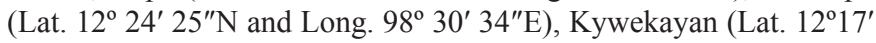

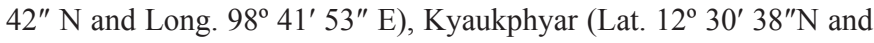
Long. $98^{\circ} 42^{\prime} 07^{\prime \prime} \mathrm{E}$ ) and Panadoung (Lat. 12 $37^{\prime} 18^{\prime \prime} \mathrm{N}$ and Long. $98^{\circ} 39^{\prime} 27^{\prime \prime} \mathrm{E}$ ), in Myeik area from December 2017 to July 2018 (Figure 1). Plant samples such as leaves, buds, flowers and fruits were collected and made herbarium sheets. Voucher specimens of mangroves growing in the study sites were also deposited in Museum of Department of Marine Science, Myeik University. All specimens were photographed digitally in color to record their natural habits, stems, root structures, leaves, fruits, and flowers. The species identification was carried out according to Selvan and Tomlinson et al. ${ }^{7-10}$ The locations and coordinates were recorded by using GPS in the study areas. The environmental parameters such as salinity and temperature of seawater, and temperature and $\mathrm{pH}$ of soils of each study site were recorded.

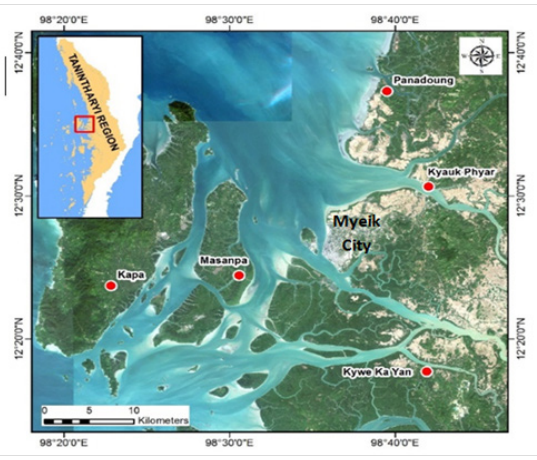

Figure I Map of the study sites (red circle) in the Myeik coastal. 


\section{Results and discussion}

A total of 21 species belonging to 11 genera from 9 families of true mangroves were recorded in the present study. They were 8 species of family Rhizophoraceae, 3 species of family Avicenniaceae, 2 species of families Sonneratiaceae, Meliaceae and Steruliaceae,
1 species of families Euphobiaceae, Myrasinaceae, Aracaceae and Plumbaginaceae. Table 1 showed the IUCN Red List, classification and occurrence of mangroves while Table 2 revealed the environmental parameters such as salinity and temperature of seawater, and temperature and $\mathrm{pH}$ of soils of each study site.

Table I Classification and occurrence of mangrove species in the study sites

\begin{tabular}{|c|c|c|c|c|c|c|c|c|}
\hline \multirow{2}{*}{$\begin{array}{l}\text { Sr. } \\
\text { No. }\end{array}$} & \multirow{2}{*}{ Species } & \multirow{2}{*}{ Family } & \multicolumn{5}{|c|}{ Locality } & \multirow{2}{*}{$\begin{array}{l}\text { IUCN } \\
\text { Red } \\
\text { List }\end{array}$} \\
\hline & & & Kapa & Masanpa & KyweKa Yan & KyaukPhyar & Panadoung & \\
\hline I. & Rhizophora apiculata & & + & + & + & + & + & LC \\
\hline 2. & R. mucronata & & + & + & + & + & + & LC \\
\hline 3. & Bruguiera gymnorhiza & Rhizophoraceae & - & + & - & - & - & LC \\
\hline 4. & B. sexangula & & - & - & + & - & + & LC \\
\hline 5. & B. cylindrica & & - & + & + & - & - & LC \\
\hline 6. & B. parviflora & & + & + & + & - & + & LC \\
\hline 7. & Ceriops tagal & & + & + & + & - & + & LC \\
\hline 8. & C. decandra & & + & + & + & - & + & NT \\
\hline 9. & Avicennia alba & & + & + & - & + & + & LC \\
\hline 10. & A. officinalis & Avicenniaceae & + & + & + & + & + & LC \\
\hline II. & A. marina & & + & + & - & + & + & LC \\
\hline 12. & Xylocarpusgranatum & Meliaceae & + & - & + & - & - & LC \\
\hline 13. & X. moluccensis & & + & - & - & + & + & LC \\
\hline 14. & Sonneratia alba & Sonneratiaceae & + & + & + & + & + & $C R$ \\
\hline 15. & S. graffithii & 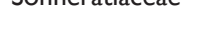 & + & + & - & + & - & LC \\
\hline 16. & Heritiera formes & & + & - & + & - & - & EN \\
\hline 17. & H. littoralis & Sterculiaceae & + & - & - & - & - & LC \\
\hline 18. & Aegialitis rotundifolia & Plumbaginaceae & - & + & - & + & + & NT \\
\hline 19. & $\begin{array}{l}\text { Aegiceras } \\
\text { corniculatum }\end{array}$ & Myrsinaceae & + & + & + & + & + & LC \\
\hline 20. & $\begin{array}{l}\text { Excoecaria } \\
\text { agallocha }\end{array}$ & Euphorbiaceae & + & - & + & + & + & DD \\
\hline 21. & $\begin{array}{l}\text { Nypa } \\
\text { fruticans }\end{array}$ & Aracaceae & + & + & + & + & + & LC \\
\hline Total & & & 17 & 15 & 14 & 12 & 15 & \\
\hline
\end{tabular}

Symbols: $(+)=$ present, $(-)=$ absent

Abbreviations: LC, least concern; NT, near threatened;VU, vulnerable; EN, endangered; CR, critically endangered; DD, data deficient. 
Table 2 The environmental parameters of the study areas during the study period

\begin{tabular}{llllll}
\hline \multirow{2}{*}{ Parameters } & \multicolumn{5}{c}{ Study areas } \\
\cline { 2 - 6 } & Kapa & Masanpa & Kywekayan & Kyauphyar & Panadoung \\
\hline Water salinity (\%॰) & 30.0 & 29.6 & 25.0 & 28.0 & 30.0 \\
Soil salinity (\%॰) & 33.0 & 29.0 & 25.0 & 29.0 & 28.7 \\
Water temperature $\left({ }^{\circ} \mathrm{C}\right)$ & 29.5 & 29.0 & 30.0 & 28.0 & 32.0 \\
Soil temperature $\left({ }^{\circ} \mathrm{C}\right)$ & 28.6 & 28.3 & 27.7 & 27.6 & 31.4 \\
Soil pH & 5.8 & 6.0 & 6.0 & 6.0 & 5.8 \\
\hline
\end{tabular}

Among the species of mangroves, Rhizophora apiculata, R. mucronata, Avicennia officinalis, Sonneratia alba, Aegiceras corniculatum, and Nypa fruticans were distributed in all 5 study sites whereas Bruguiera gymnorrhiza and Heritiera littoralis are rarely found only in one study site (Table 1). Sonneratia alba recorded as critically endangered species in the IUCN Red list was remarkably found in all study sites of Myeik coastal areas.

Key to the species of mangroves along the Myeik coastal areas

1a Trees with stilt roots- 2

1b Trees without stilt roots- 3

2a Leaves apiculate, flower stalk short- Rhizophora apiculata Blume (Figure 2A-F)

2b Leaves mucronate, flower stalk long- $R$. mucronata Lamk (Figure 3A-F)

3a Stipules present- 4

3b Stipule absent- 9

4a Leaf tip is pointed; 8-13 calyx lobes; larger trees with many knee-shaped roots- 5

$4 \mathrm{~b}$ Leaf tip is rounded; with 5 calyx lobes; buttress originating stilt-like roots- 8

5a Flowers solitary, one flower on each stalk- 6

5b Flowers cluster, 3-4 flowers on each stalk-7

6a Leaves up to $4-15 \mathrm{~cm}$, often reddish leaf stalk; flowers redBruguiera gymnorhiza (L.) Lamk(Figure 4A-F)

$6 \mathrm{~b}$ Leaves up to $4-10 \mathrm{~cm}$, green leaf stalk; flowers yellowB.sexangula (Lour.) Poir(Figure 5A-E)

7a Leaves elliptical, inflorescence mostly 3-flowered- $B$. cylindrica Blume(Figure 6A-F)

7b Leaves oblong, inflorescence mostly 4-7 flowered- $B$. parviflora (Roxb.) W. \& A. exGriff.(Figure 7A-F)

8a Leaves oval, calyx lobes curled back; hypocotyls $25-30 \mathrm{~cm}$ long-Ceriops tagal (Perr.) C.B. Rob(Figure 8A-F)

$8 \mathrm{~b}$ Leaves obovate, calyx lobes not curled back hypocotyls 8-15cm long- C.decandra(Griff.) Ding Hou(Figure 9A-F)

9a Trees with pneumatophores/respiratory roots- 10

9b Trees without pneumatophores- 18

10a Trees with pencil-shaped pneumatophores- 11 10b Trees with peg-shaped, conical-shaped or loop-shaped pneumatophores- 13

11a Leaves lanceolate, flowers dull yellow, fruits chill-shapedAvicennia alba Blume (Figure 10A-F)

11b Leaves elliptical, flowers orange-yellow, fruits ovoid- 12

12a Pneumatophores long, bark rough and brown color, leaves obovate to oblong- A. officinalis L. (Figure 11A-F)

12b Pneumatophores short, bark smooth and yellowish green color, leaf margin rolled backwards- A. marina (Forssk.) Vierh. (Figure 12A-F)

13a Leaves compound, bark with lenticels or fissured- 14

13b Leaves simple, bark with peeling in patches or fissured- 15

14a Leaflets rounded at the tip, fruit brownish-red, buttresses flattened and ribbon-like plank root, bark with irregular patchesXylocarpus granatum Konig (Figure 13A-F)

14b Leaflets exstipulate, fruit green, buttresses short and peglike pneumatophores bark longitudinal fissured- X. moluccensis (Lamk) Roem. (Figure 14A-E)

15a Leaves underside green, flowers large, fruit globose or capsule, seed numerous- 16

$15 \mathrm{~b}$ Leaves underside white or silvery, flowers small, fruit subglobose, seed one- 17

16a Leaves obovate to rounded, fruit ball-shaped with long style and short calyx lobe- Sonneratia griffithii Kurz. (Figure 15A-F)

$16 \mathrm{~b}$ Leaves ovate to oblong, fruit cup-shaped, concave on the side of short style, big long calyx lobe- S. alba Smith (Figure 16AF)

17a Bark with many lenticels, leaf elliptical oblong, brown leaf underbeneath- Heritiera fomes Buch. Ham. (Figure 17A-D)

17b Bark with longitudinal fissured, leaf oblong, whitish leaf- $H$. littoralis Dryand (Figure 18A-E)

18a Shrubby trees, leaf oval, long petiole, apex rounded to shortly pointed, leaf spongy; leaves green and fleshy, small buttresses roots-Aegialitis rotundifolia Roxb. (Figure 19A-F)

$18 \mathrm{~b}$ Small to medium trees; leaves simple, leaf tip acute or rounde, small plank-like or wavy roots- 19

19a Small trees or rarely shrubs, leaf tip rounded- Aegiceras corniculatum (L.) Blanco (Figure 20A-F)

19b Small to medium trees, leaf tip acute- 20 
20a Leaves oblong, flowers yellowish green, fruit 3-lobed, green color-Excoecaria agallocha L. (Figure 21A-E)

20b Leaves lanceolate, flowers brick red to yellow, fruits globose, dark brown in colour- Nypa fruticans Wurmb. (Figure 22A-D)
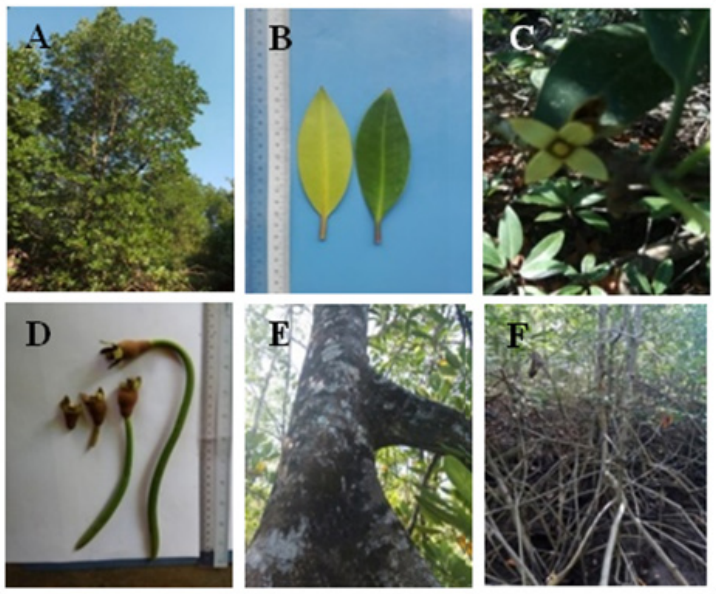

Figure 2 Rhizophora apiculata (A) Habit. (B) Leaves. (C) Flower. (D) Fruits. (E) Stem and (F) Root.
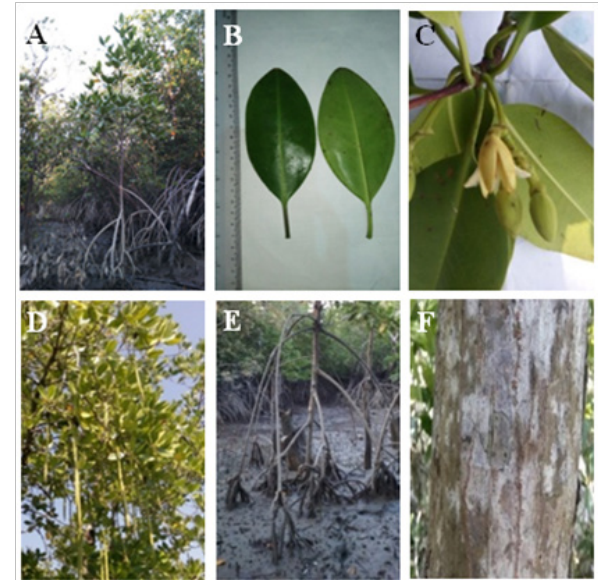

Figure 3 Rhizophora mucronata (A) Habit. (B) Leaves. (C) Flower. (D) Fruits. (E) Stem and (F) Root
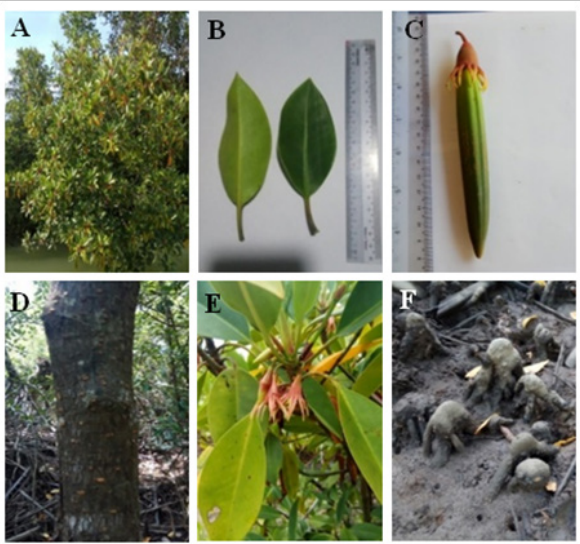

Figure 4 Bruguiera gymnorhiza (A) Habit. (B) Leaves. (C) Flower. (D) Fruits. (E) Stem and (F) Root
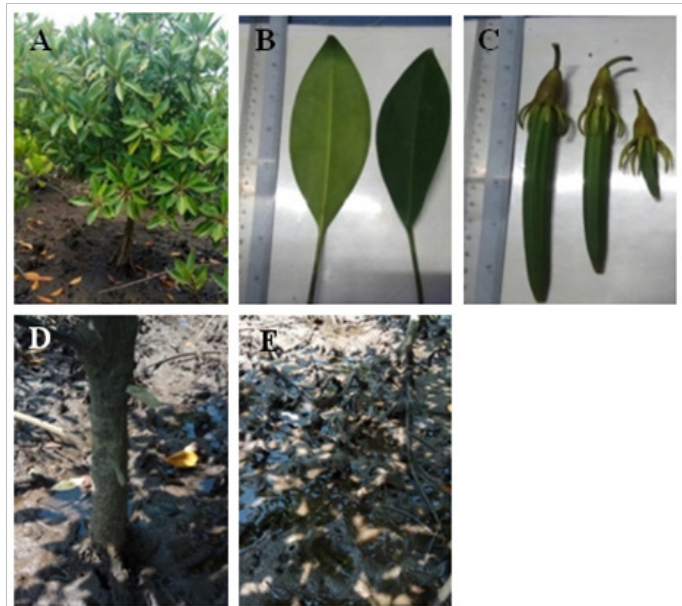

Figure 5 Bruguiera sexangula (A) Habit. (B) Leaves. (C) Flower. (D) Fruits and $(\mathrm{E})$ Stem
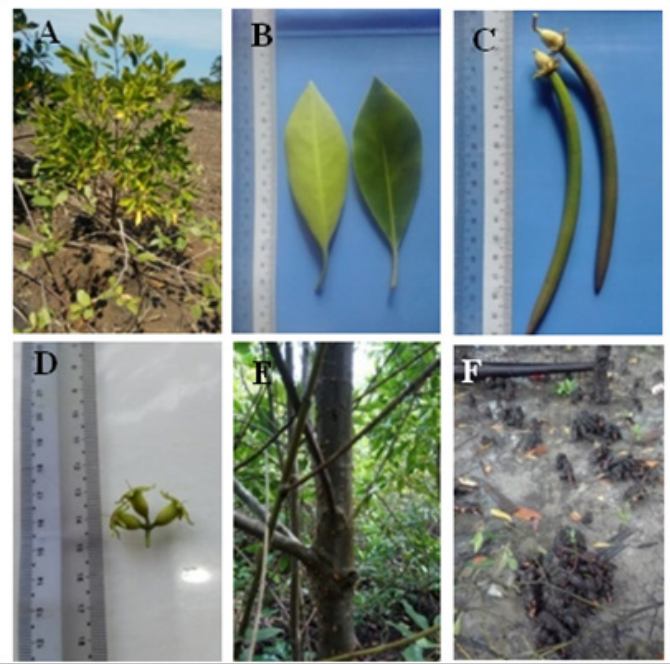

Figure 6 Bruguiera cylindrica (A) Habit. (B) Leaves. (C) Flower. (D) Fruits. (E) Stem and (F) Root
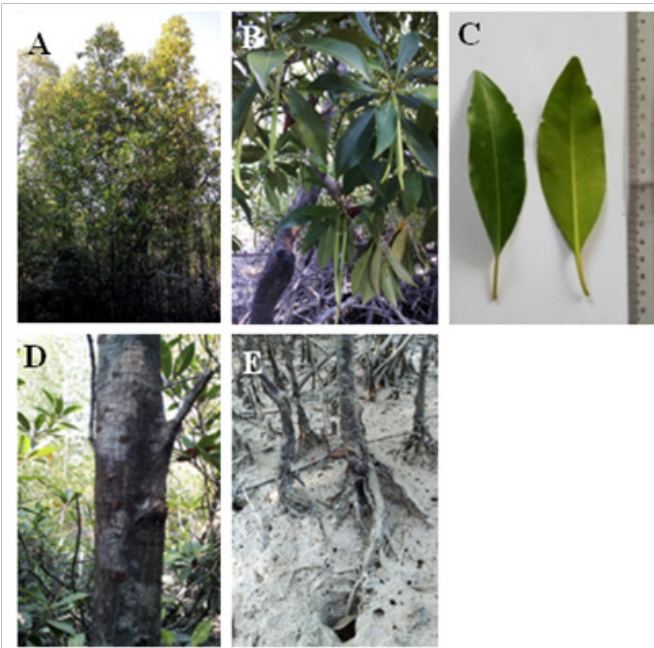

Figure 7 Bruguiera parviflora (A) Habit. (B) Leaves. (C) Flower. (D) Fruits and (E) Stem 

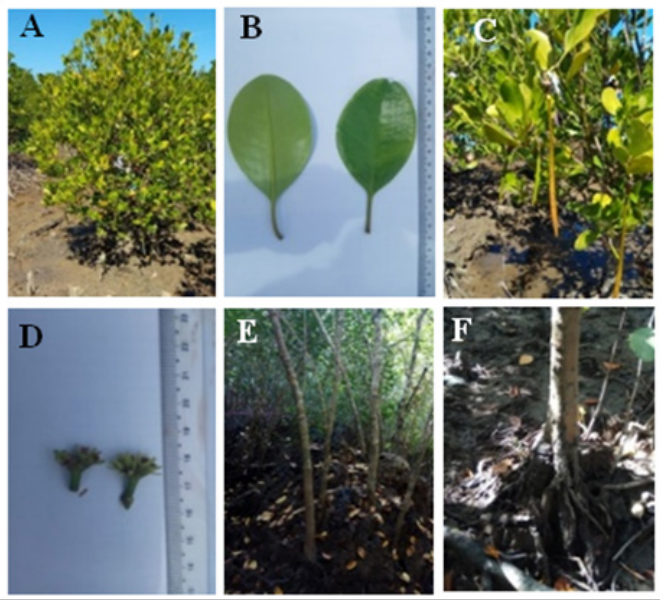

Figure 8 Ceriopstagal (A) Habit. (B) Leaves. (C) Fruits. (D) Inflorescence. (E) Stem and (F) Root.

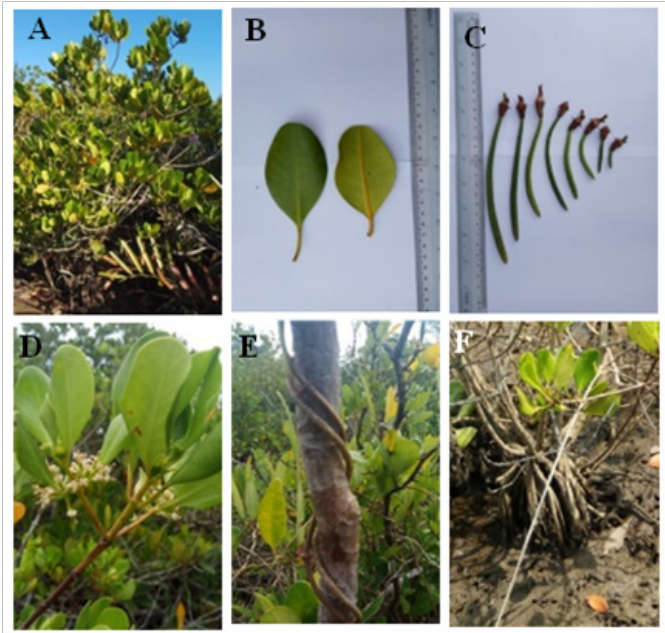

Figure 9 Ceriops decandra (A) Habit. (B) Leaves. (C) Fruits. (D) Inflorescence. (E) Stem and (F) Root.

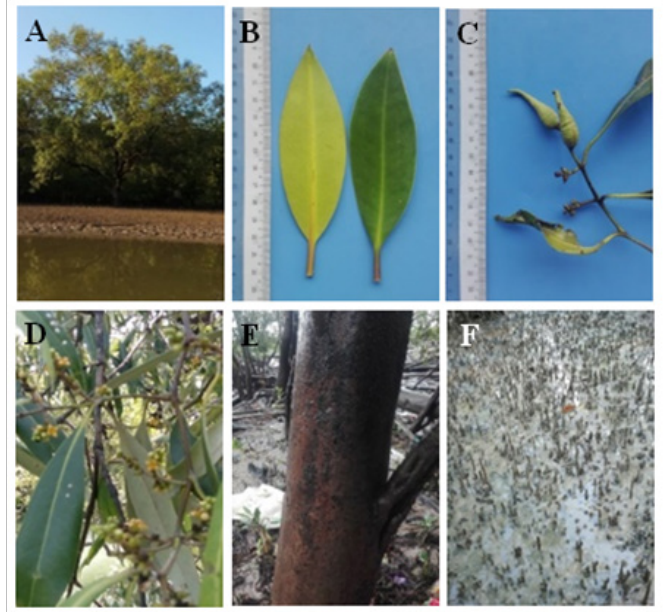

Figure 10 Avicennia alba (A) Habit. (B) Leaves. (C) Fruits. (D) Inflorescence. (E) Stem and (F) Root.
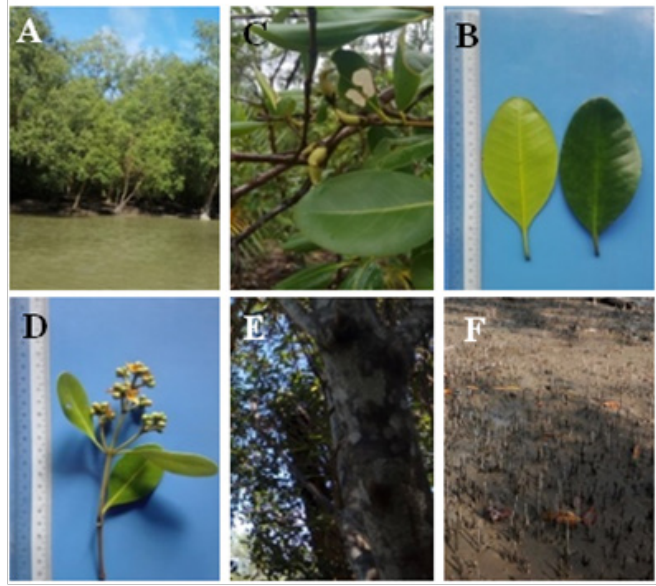

Figure II Avicennia officinalis (A) Habit. (B) Leaves. (C) Fruits. (D) Inflorescence. (E) Stem and (F) Root
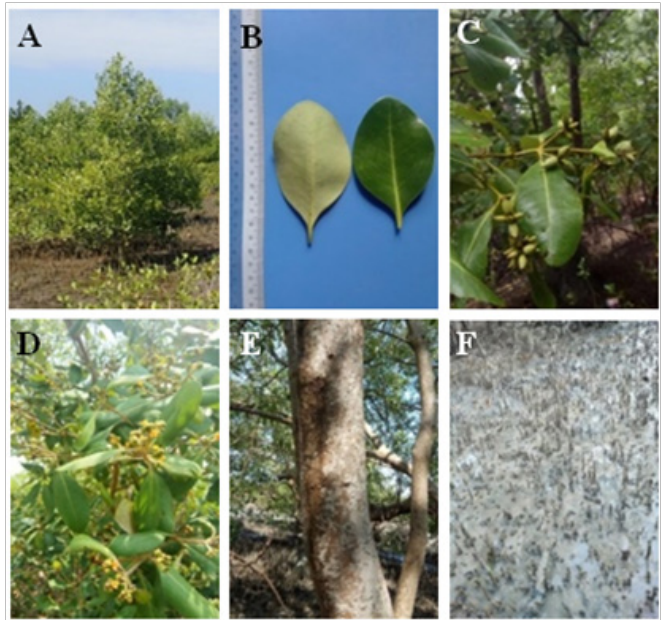

Figure I 2 Avicennia marina (A) Habit. (B) Leaves. (C) Fruits. (D) Inflorescence. (E) Stem and (F) Root
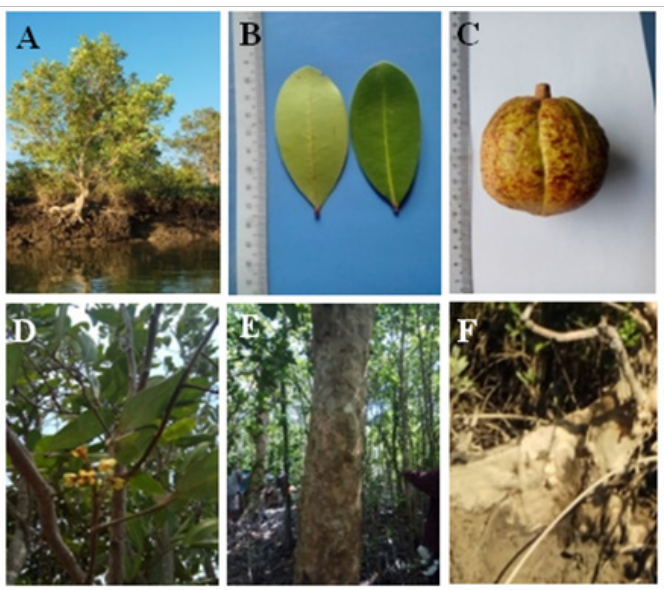

Figure 13 Xylocarpus granatum (A) Habit. (B) Leaves. (C) Fruits. (D) Inflorescence. (E) Stem and (F) Root. 

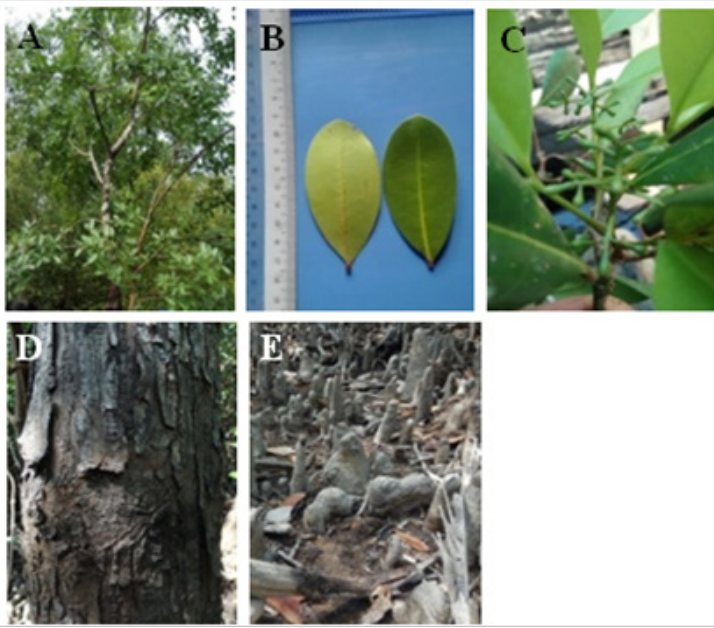

Figure 14 Xylocarpus moluccensis: (A) Habit. (B) Leaves. (C)Inflorescence. (D) Stem and (E) Root.
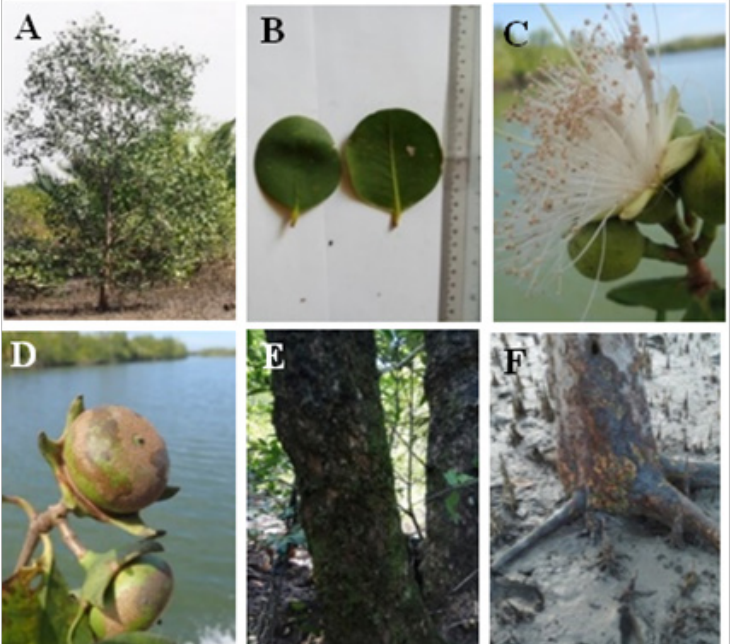

Figure 15 Sonneratia griffithii (A) Habit. (B) Leaves. (C) Inflorescence. (D) Fruits. (E) Stem and (F) Root.
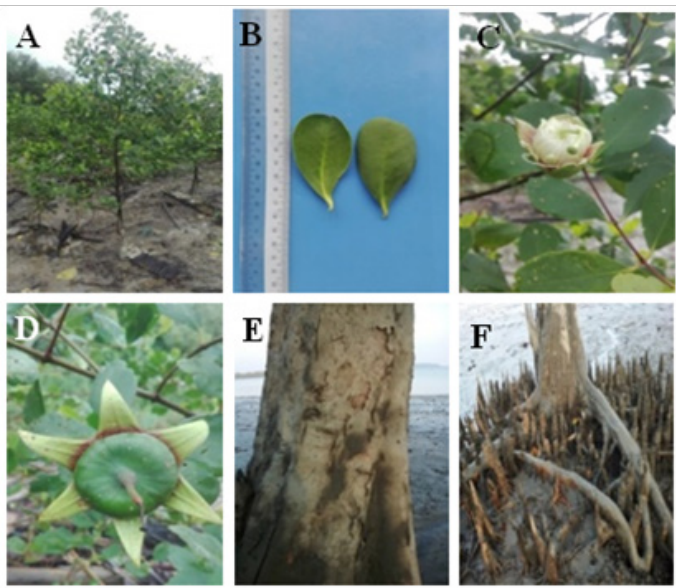

Figure 16 Sonneratia alba (A) Habit. (B) Leaves. (C) Inflorescence. (D) Fruits. (E) Stem and (F) Root
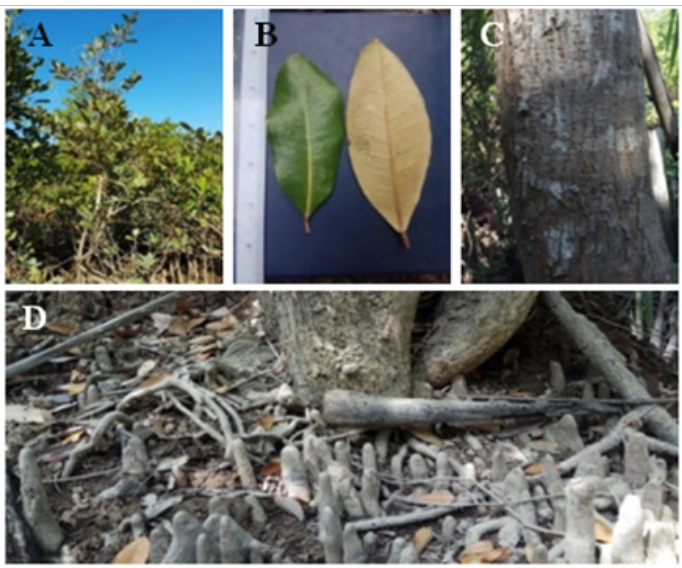

Figure 17 Heritiera fomes (A) Habit. (B) Leaves. (C) Stem and (D) Root.
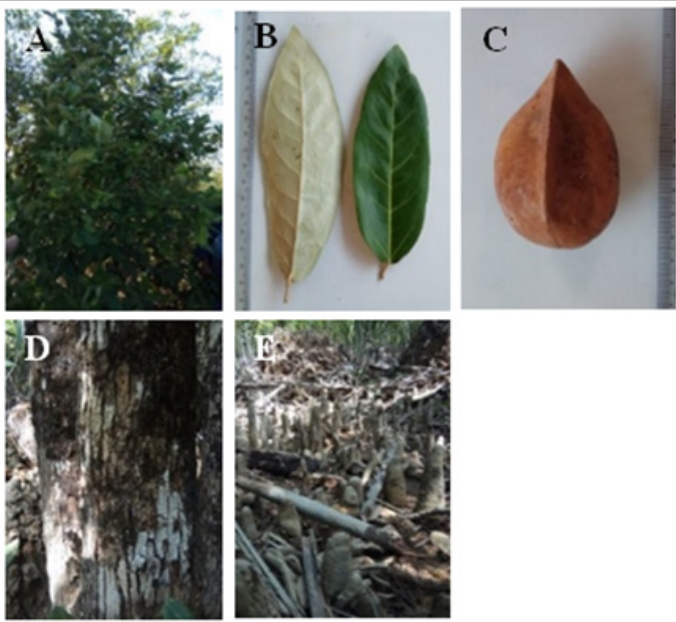

Figure 18 Heritiera littoralis (A) Habit. (B) Leaves. (C) Fruits. (D) Stem and (E) Root.
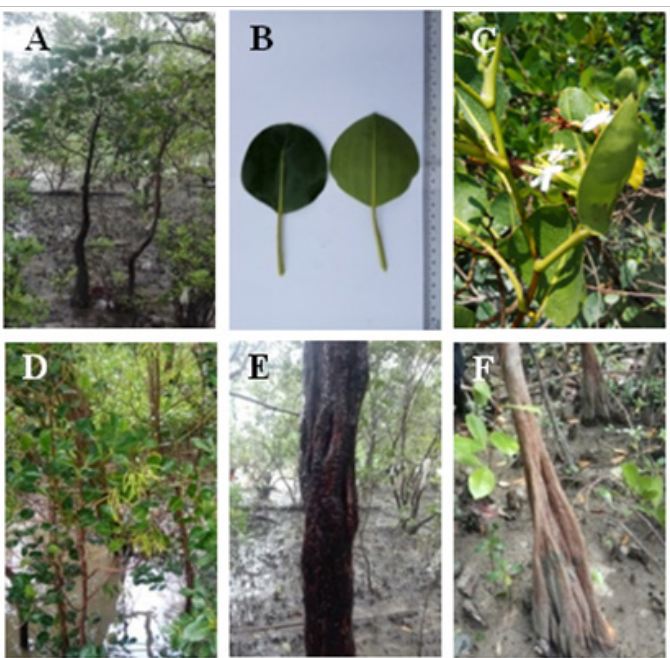

Figure 19 Aegialitis rotundifolia (A) Habit. (B) Leaves. (C) Inflorescence. (D) Fruits. (E) Stem and (F) Root. 

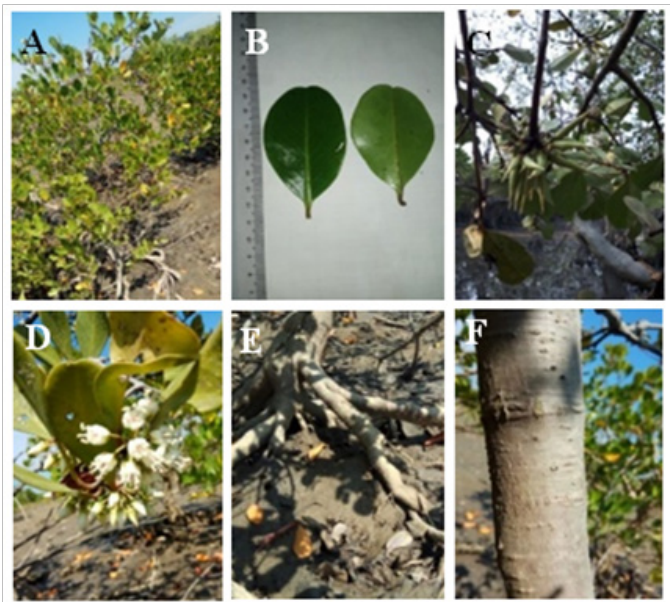

Figure 20
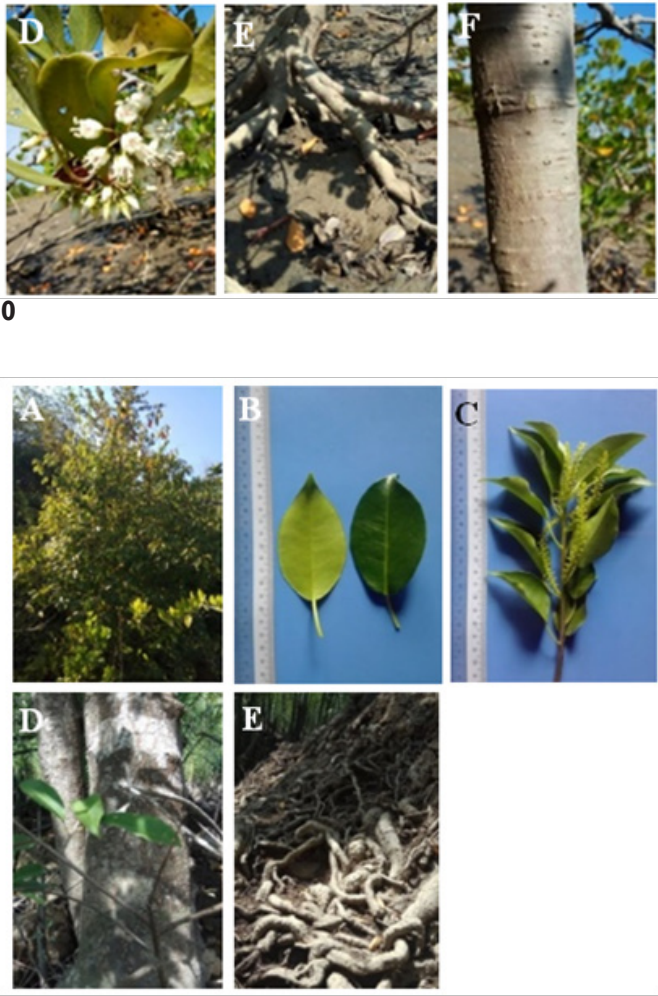

Figure 21
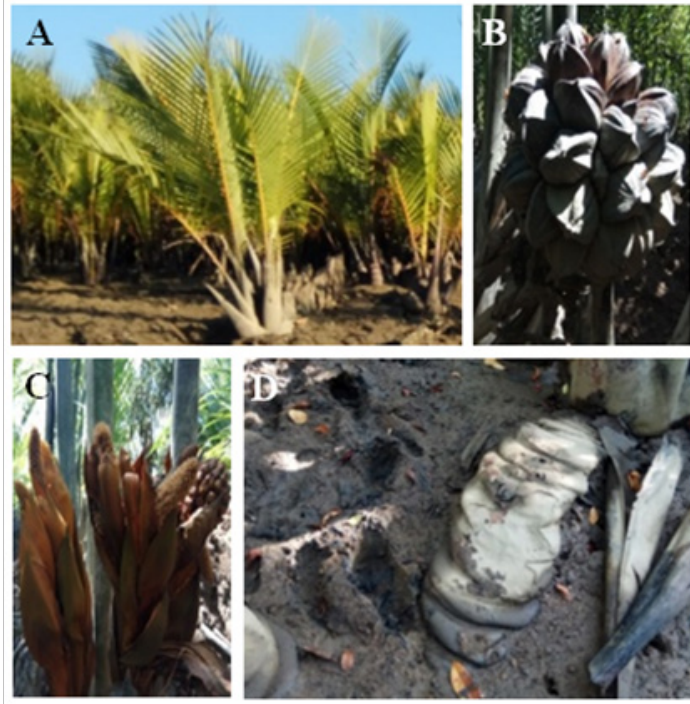

Figure 22 Nypa fruticans (A) Habit. (B) Inflorescence. (C) Fruits and (D) Root.
In the previous studies, a total of 50 species ${ }^{11} 44$ species $^{4}$ and 30 species of true mangroves and its associates ${ }^{6}$ were recorded in various coastal areas of Myeik.

The present studies demonstrated that all plants of mangroves, especially Avicennia alba, Sonneratia alba and Rhizophoramucronata can grow well on all soil types of substrates: muddy, very soft muddy and sandy mud areas. ${ }^{12}$ revealed that although mangroves possess a variety of morphological and physiological adaptations for life in a stressful habitat, interspecific differences in survival and growth under different environmental conditions can shape their local and geographic distributions. Rejil ${ }^{13}$ also mentioned that the repeated flooded and well drained soils support good mangrove growth and high species diversity and they grow poorly in stagnant water. Similarly, some areas of Masanpa and Kapa have the big and healthy trees with the great forest in this study. These areas are always flooded with the water of high salinity.

Regarding the environmental parameter measurements, the water salinity $(30.0 \%)$ was highest at Kapa and Panadoung. Kywe kayan had the lowest water salinity (25.0\%) because of rainfall during study period. There was not only highest number of species diversity but also highest salinity in Kapa. This result reveals that the water salinity can influence the species diversity as reported by Weerasinghe et al. ${ }^{14}$ who mentioned the spatial differences of the floristic composition and the diversity reflect the salinity tolerance ability of the different mangrove species.

Cunha-Lignon et al. ${ }^{15}$ reported that the distribution of mangrove species was subjected to various concentrations of salinity and nutrient levels. They pointed that the environmental parameter changes in hydrology and water quality were important indicators, as change in these parameters could influence colonization, succession and zonation. Individual mangrove species rarely occupy entire estuaries from sea mouth to the tidal limit upstream. Likewise, Barik et al. ${ }^{16}$ mentioned that each mangrove species has optimal salinity range for its preferred habitat. The present study also approved that Rhizophora apiculata, R. mucronata and Heritiera litoralis were conspicuously dominant in the shorelines of Kapa with high salinity (Tables 1-2).

The mangrove products were over exploited commercially on some of study areas for many uses. Therefore, the management of mangrove ecosystem is vital role for long term sustainable yield and reforestation. Mangrove systems provide a wide range of ecosystem services and the entire mangrove intertidal system should be conserved. Mangrove forests are among the world's most productive ecosystems. Mangroves and mangrove ecosystems have been studied extensively but still remain poorly to be understood. With continuing degradation and destruction of mangroves, there is a critical need to better understanding them. ${ }^{17}$

Many baseline data on the mangrove ecology is still needed in Myanmar towards the proper conservation works. Among the study areas, the mangrove area in Kyaukphyar is being degraded because of urban development and industrialization. Therefore, there is a need to maintain and manage of mangrove forest in this area. The results of this study suggests that the contribution of knowledge to local people for awareness on values of mangrove ecosystem is still needed to maintain the sustainability of fishery resources and livelihoods of the local communities relying on mangrove ecosystems in Myeik areas. 


\section{Acknowledgements}

We wish to express our sincere gratitude to Rector Dr. Ni Ni Oo and Pro-Rector, Dr. Win Win Than, Myeik University, for their permission to conduct this research work. We are greatly indebted to Dr. Nyo Nyo Tun, Professor and Head, Department of Marine Science, Myeik University, for her encouragement throughout the study period. We would like to acknowledge to U Soe-Htun, Chairman, Marine Science Association Myanmar, for reading this manuscript. We sincerely thank the local villagers for their helpful assistance in the field works. The first author, Tin-Zar-Ni-Win, would like to thank her beloved parents, for their physical, moral and financial supports throughout this study.

\section{Funding}

None.

\section{Conflicts of interest}

The author declares that there are no conflicts of interest.

\section{References}

1. Myint Pe 2002. National report of Myanmar- On the sustainable management of the Bay of Bengal Large Marine Ecosystem (BOBLME). GCP/RAS/179/WBG. 2002; $61 \mathrm{p}$

2. Kyaw Thura, Nang Mya Han, San ThaTun, et al. Study on the distribution of Family: Sonneratiaceae in Myeikareas. Universities Research Journal. 2013; 6:1-16.

3. Spalding M, Kainuma M, Clins L. World mangrove atlas, 319London, Washington, DC: Earthscan. 2010;39:107-109.

4. San ThaTun, Win Hteik, Kyaw Thura. 2014. Survey of mangroves in Auckland Bayand adjacent areas, Kyun-Suand BokePyinTownships, Tanintharyi Region, Myanmar. 2014. 28 p.

5. Zockler C, Aung C. The mangroves of Myanmar. In: Gul B, editor Sabkha Ecosystems, Task for Vegetation Science VI, Springer Nature Switzerland. 2019;16:253-269.
6. Pyae Sone Aung. Mangrove of Shwe Bay area, Myeik, Tanintharyi Region. Unpublished MSc Thesis, Department of Marine Science, Myeik University. 2015; 34p

7. Selvan V, Eganathan P, Karunagaran VM, et al. Mangrove plants of Tamil Nadu. M.S. Swaminathan Research Foundation. Chennai. 2004; 56 p.

8. Shin SL, Muhamad A, Joanne T. Mangrove guidebook for Malaysia. The Global Environment Facility, Small Grants Programme (GEF-SGP). Wetlands International, Malaysia, 2015; p. 1-143.

9. Tomlinson PB. The botany of mangroves. Cambridge University Press, Cambridge, London. 1986; 413 p.

10. Tomlinson PB. The botany of mangroves. Cambridge University Press, Cambridge, London. 2016; 406 p.

11. San ThaTun, Tint Swe, Tint Tun. 2008. The preliminary study on the mangrove of Lampi Island and adjacent areas, Myanmar. 2008; $18 \mathrm{p}$.

12. Dangremond EM, Feller IC, Sousa WP. Environmental tolerances of rare and common mangroves along light and salinity gradients, Community Ecology-Oecologia. 2015; 12 p.

13. Rejil T. Mangrove vegetation in the selected mangrove ecosystems in Kerala. Department of Marine Biology. School of Marine Science and Technology. India. 2012; 277 p.

14. Weerasinghe E, Piyadasa UKR. Mangrove diversity across salinity gradient in Negombo Estuary. Sri Lanka. Indo-Sri Lanka Research Project. 2016. 20 p.

15. Cunha-Lignon M, Coelho C, Almeida R, et al. Characterization of mangrove forest types in view of conservation and management, a review of mangals at the CananeiaRegion, Sao Paulo State, Brazil. 2018; p. 349-353.

16. Barik J, Mukhopadhyay A, Ghosh T, et al. Mangrove species distribution and water salinity: an indicator species approach to Sundarban. Journal of Coastal Conservation. 2017; 22: 361-368.

17. Kathiresan K, Bingham BL. Biology of mangroves and mangrove ecosystems. Advances in Marine Biology. 2001;40:81-251. 